\title{
Prevelance of Helminth Parasites in Sheep of Medak District, Telangana India
}

\author{
Nagesh . $D^{1}$, Vanita Das . $V^{2}$ \\ ${ }^{1,2}$ Dept. of Zoology, University College of Science Osmania University, Hyderabad- 500 007, Telangana, India
}

\begin{abstract}
The Prevalence of helminth parasites in sheep of Medak district, Telangana state. Was investigated for the year 2011-2012. A total of 900 faecal samples from different study areas were collected for carpological examination in which 499 (54.44\%) were found positive for various types of helminthic infections. Two types of Nematodes (15.0\%) Namely, Trichuris ovis, and Haemonchus contortus, Three types of Trematodes (24.2\%), Namely Paramphistomum, F.hepatica and F. gigantica and One Cestode (14.8\%), that are Moniezia expansa. were identified. The infection also found throughout the year in different seasons, in summer (43.3\%), winter (55.3\%) and in Rainy season (64.66\%). Seasonal prevalence of infections indicated that the Trematode infection was highest in rainy season and followed by winter and summer. Some other epidemiological parameters like species wise, sex wise also revealed during the present study. The present study shows the severity of infection in the area and need to develop suitable management strategies for the diagnosis of Helminth infections.
\end{abstract}

Keywords: Incidence, Medak, Nematodes, Trematodes, cestode, Sheep

\section{Introduction}

Helminths or Worms cause a wide range of health problems to both male and female animals (Colley, 2001). Helminthiasis in large part is caused by members of the phyla Nematodes, and Platyhelminthes (Kennedy, 2001). The species belong to both phyla occupy numerous niches within their mammalian hosts, ranging from intestinal lumen to intravascular and even intracellular sites (Little word, 2001). They are responsible for substantial loss of productivity in the livestock industry. Their harmful effects on these animals range from gastroenteritis, anorexia, abdominal distension, diarrhoea, emaciation, and so forth, all of which result in serious economic losses to the farmer and the nation (Junaidu, 1997). Similarly, they constitute a major impediment to efficient and profitable livestock production (Akerejola, 1999).

Parasitism is of supreme importance in many agroecological zones and still a serious threat to the livestock economy worldwide (Vercruysse and Claerebout, 2001).Infection with sheep suffers from many infectious diseases and heavy economic losses occur due to mortality as well as morbidity. Helminth diseases alone are responsible for 5 percent mortality and 10 percent morbidity in sheep (Chakerborty and Lodh, 1994). . These helminths have been recognized as a major factor limiting sheep production throughout the world. Telangana State is primarily an agricultural state and sheep rearing is one of the major sources of economy to farming community and other nomads. Ruminants, cattle, goats and sheep represent an important source of animal protein in many countries of the world, supplying a good percentage of the daily meat and dairy products in cities and villages in such countries including India (Nwosu, 2007). Apart from being the source of animal protein, their wastes are also very important in agriculture (Nawathe, 1985). Due to improper management and unhygienic conditions sheep suffers from various helminthic infections. No reports are available on helminth parasites in sheep of Medak dist. Therefore, present study was planned to study season wise incidence picture of most prevalent helminths in sheep of Medak district. To enable the sheep breeders and veterinarians in planning the prophylactic measures well in advance.

\section{Materials and Methods}

The study was conducted for a period of One year 2011(month) to 2012(month) at Medak district in Telangana State .A total of 900 faecal samples of sheep were collected randomly and study season wise, Species wise, and age wise.

\section{Collection of faecal samples:}

Faecal samples were collected from sheep in the four divisions of the Medak Dist. The samples were collected in clean labelled sterile vials, preserved in $10 \%$ formalin and taken to the laboratory for microscopic examination.

\section{Laboratory Technique}

Direct microscopic examination and sodium chloride floatation technique were used to process the faecal samples. Identification of the eggs and oocysts were made on the basis of morphology as per Yamaguti (1959) and Solusby (1982). Faecal smears were prepared from fresh faecal samples on glass slides using saturated salt solution and covering with cover slips. The slides were examined microscopically for helminth eggs, oocysts and larvae using 10x and 40x objectives.

\section{Results and Discussion}

A total of 900 faecal samples of sheep were examined through faecal sample examination, of which 499 were infected with One or more species of helminths indicating $54.4 \%$ overall prevalence. Six species of helminths were identified; out of them three were trematodes, namely, Fasciola hepatica (11.5\%), Fasciola gigantic (4.1\%), and Paramphistomum spp. (8.7\%), two were nematodes, namely, Trichurisspp. (4.4\%), and Haemoncus spp. (10.5\%).One spp.of cestodes were detected namely Moneizia expansa(16.0\%). It was observed that prevalence of 


\section{International Journal of Science and Research (IJSR) \\ ISSN (Online): 2319-7064 \\ Index Copernicus Value (2013): 6.14 | Impact Factor (2015): 6.391}

moneiziaexpansa (16.0\%) was the highest, whereas Fasciola gigantica $(4.1 \%)$ was the lowest the highest incidence was observed in Rainy season, followed by winter and summer as shown in table 1. (Table 2).

Table 1: Seasonal occurrence of helminth parasites in sheep in Medak dist.

\begin{tabular}{|c|c|c|c|c|c|c|c|}
\hline Sno. & Season & $\begin{array}{c}\text { No. of Faecal } \\
\text { Samples Collected }\end{array}$ & $\begin{array}{c}\text { No. of Samples } \\
\text { Found Positive }\end{array}$ & $\begin{array}{c}\text { \% of Samples } \\
\text { Infective }\end{array}$ & Nematodes & Trematodes & Cestodes \\
\hline 1 & WINTER & 300 & 176 & 55.33 & $43(13.6)$ & $72(24)$ & $61(20.3)$ \\
\hline 2 & SUMMER & 300 & 105 & 43.33 & $31(10.3)$ & $35(11.6)$ & $39(13)$ \\
\hline 3 & RAINY & 300 & 218 & 64.66 & $61(20.3)$ & $113(37.6)$ & $44(14.6)$ \\
\hline TOTAL & & $\mathbf{9 0 0}$ & $\mathbf{4 9 9}$ & $\mathbf{5 4 . 4 4}$ & $\mathbf{1 3 5}(\mathbf{1 5 . 0})$ & $\mathbf{2 2 0}(\mathbf{2 4 . 2})$ & $\mathbf{1 4 4 ( 1 6 . 0 )}$ \\
\hline
\end{tabular}

Figure: 1. Seasonal occurrence of helminth parasites in sheep in Medak dist

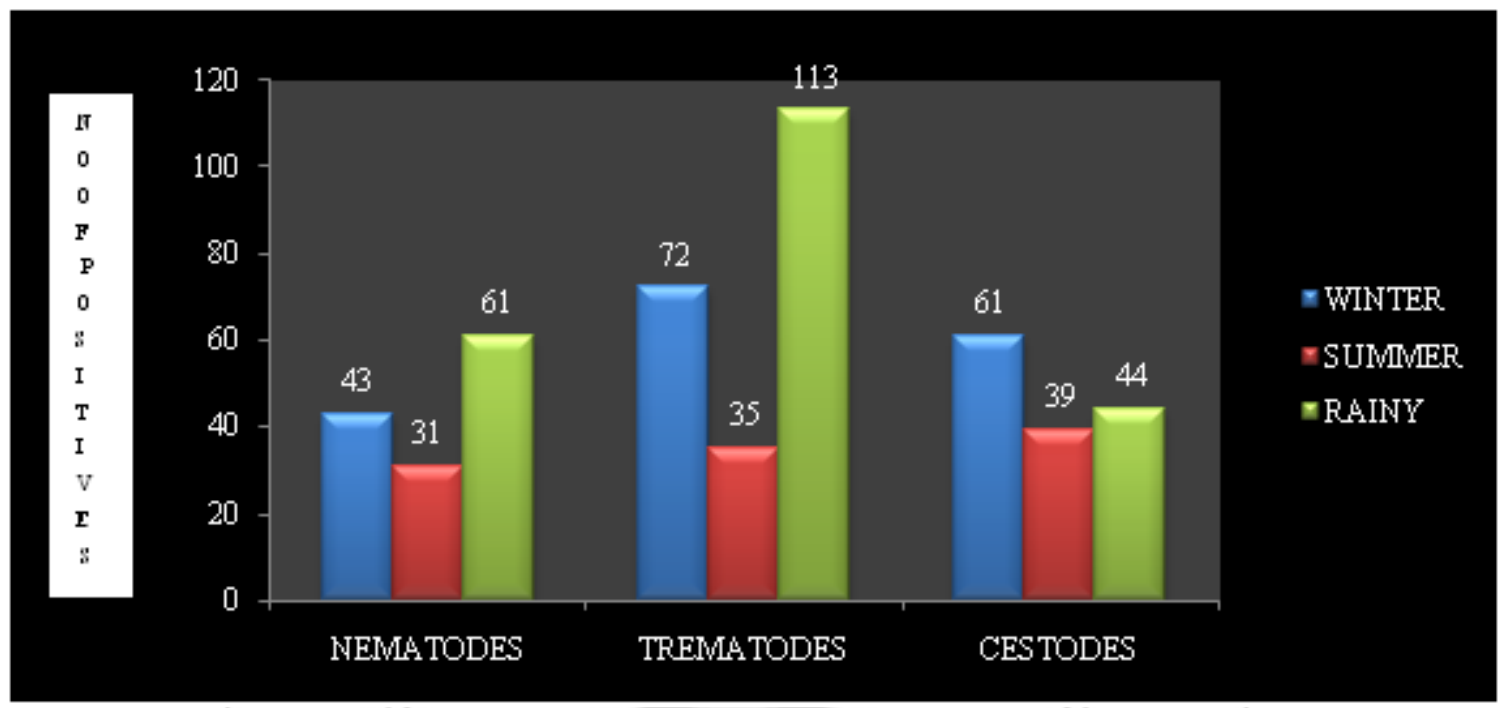

Table 2: The infection percentage of different species of Helminth parasites in sheep of Medak dist.

\begin{tabular}{|c|c|c|c|c|c|c|c|}
\hline \multirow{2}{*}{ SNO. } & \multirow{2}{*}{ SEASON } & \multicolumn{2}{|c|}{ NEMATODES } & \multicolumn{3}{c|}{ TREMATODES } & CESTODES \\
\cline { 3 - 8 } & & HAEMANCUS & TRICURIS & PARAMPHISTOMUM & F.HEPATICA & F.GIGANTIC & MONEIZIA. SP. \\
\hline 1 & WINTER & $29(9.6)$ & $14(4.6)$ & $28(9.3)$ & $34(11.3)$ & $10(3.0)$ & $61(20.3)$ \\
\hline 2 & SUMMER & $23(7.6)$ & $08(2.6)$ & $12(4.0)$ & $17(5.6)$ & $06(2.0)$ & $39(13.0)$ \\
\hline 3 & RAINY & $43(14.3)$ & $18(6.0)$ & $39(13.0)$ & $53(17.0)$ & $21(7.0)$ & $44(14.6)$ \\
\hline \multicolumn{2}{r}{ Total } & $95(10.5 \%)$ & $40(4.4 \%)$ & $79(8.7 \%)$ & $104(11.5 \%)$ & $37(4.1 \%)$ & $144(16.0 \%)$ \\
\hline
\end{tabular}

Table 3: Sex wise occurrence of Helminth parasites in sheep of Medak dist

\begin{tabular}{|c|c|c|c|}
\hline Sex & $\begin{array}{c}\text { No. of faecal } \\
\text { samples examined }\end{array}$ & $\begin{array}{c}\text { No. of faecal } \\
\text { samples infected. }\end{array}$ & $\begin{array}{c}\text { Prevalence } \\
(\%)\end{array}$ \\
\hline Male & 250 & 103 & 41.2 \\
\hline Female & 650 & 396 & 60.9 \\
\hline
\end{tabular}

The prevalence of parasites in rainy, winter, and summer were respectively $64.66 \%, 55.33 \%$, and $43.33 \%$, similarly prevalence of parasites was higher in females $(60.9 \%)$ as compared to male $(41.2 \%)$ as shown in table 3.

The study showed that the overall prevalence of Helminth parasites in sheep of medak dist. (54.44\%). The highest prevalence of parasites in Rainy season and winter is in consent with many reports around the world (Nasreen et al., 2005; Fayaz et al., 2007; Kuchay et al., 2011; Yadav et al., 2006; Khajuria et al., 2003. Makdoomi et al., 1995).

The rainy season which starts in the spring and earlier in summer made the environmental conditions more favourable for the development and survival of parasitic stages and led to increased availability of infective larvae in the rainy and post rainy season. It is well documented that gastrointestinal parasitism in grazing animals is directly related to the availability of larvae on pasture and seasonal pasture contamination (Smeal et al., 1980).

The study further revealed that sex of the animals showed an association with the prevalence of the parasites. It was observed that the females were more infected than the males. The influence of sex on the susceptibility of animals to infections could be attributed to genetic predisposition and differential susceptibility owing to hormonal control. The physiological peculiarities of the female animals, which usually constitute stress factors thus reducing their immunity to infections, and for being lactating mothers, females happen to be weak and malnourished, as a result of which they are more susceptible to the infections besides some other reasons (Blood and Radostists, 2000) Differences in susceptibility to infection between sexes have been observed by various workers (Gulland and Fox, 1992; Gorski et al., 2004; Gauly et al., 2006.)

\section{Conclusion}

In conclusion, various Helminth parasites have been found in sheep in Medak Distict. Hence, the high prevalence rate 


\section{International Journal of Science and Research (IJSR) \\ ISSN (Online): 2319-7064}

Index Copernicus Value (2013): 6.14 | Impact Factor (2015): 6.391

of Helminthiasis in livestock needs to be checked periodically, Regular control measures should be practiced and farmers educated in the proper use of anti helminthic drugs. Epidemiology facts suggests that high standard of sanitation in modern animal husbandry will prevent exposure of livestock to graze in deteriorated and environmentally polluted range lands will be effective in controlling the diseases.

\section{Acknowledgement}

The author is grateful to Dr. V. Vanita Das Professor Department of zoology Osmania University for encouragement and reviewing the manuscript and for valuable suggestions. The authors are thankful to Asst. Director of animal husbandry Sangareddy for providing the facilities to carry out the work.

\section{References}

[1] Ahmad, F.; Tariq, K. A.; Chishti, M. Z. 2007. Epidemiological studies on haemonchosis of sheep in Kashmir valley. Oriental Sci. 12: 43-47.

[2] Bali, H. S., 1976. A survey of helminth parasites of sheep (Ovis aries) in Jammu and Kashmir. J. Anim. Hlth. Prod, v (IV): 1-2.

[3] 3.Bhat, M. S.; Sudhan, N. A.; Shahardar, R. A.; Mir, A. Q. 2007. Prevalenceof gastrointestinal nematodosis in sheep in Kashmir valley. Journal of Veterinary parasitological, 21(1): 89-91.

[4] Blood, D. C. Radostitis, O. M (2000) Veterinary Medicine, 7th Edn. The English Language Book Society, Bailliere Tindall, London.

[5] Chakeraborty, D. and Lodh, C., 1994. Studies on blood and biochemical profile in naturally infected goats. Indian vet. J., 3: 286-288.

[6] Dhar, D. N.; Sharma, R. L. and Bansal, G. C. 1982. Gastrointestinal nematodes in sheep in Kashmir. Veterinary Parasitology, 11: 271-272.

[7] Dunn AM (1978). Veterinary Helminthology. 2nd edition London: William Heinemann Medical Books.

[8] Gorski, P., Niznikowski, R., Strzelec, E.; Gajewska, A. and Wedrychowicz, H. 2004.

[9] Prevalence of protozoan and helminth internal parasite infections in goat and sheep flocks in Poland.

[10] Arch. Tierz. Dummerstorf, 47: 43-49. www.sciencejournal.in Volume 2 Issue 1 (2013) ISSN: 2319 - 314X (Print); 2319 - 3158 (Online) (C) 2013 DAMA International.

[11] Muzaffar Rasool Mir*, Chishti M.Z. INCIDENCE OF GASTROINTESTINAL NEMATODOSIS IN SHEEP OF JAMMU.

[12] A. U. Junaidu and S. G. Adamu (1997). Survey of Gastrointestinal Helminth Parasites of Dogs of Public Health Importance in Sokoto Metropolis". In Proceedings of the 22nd Annual Conference of the Nigerian Society of Animal Production, Abubakar Tafawa Balewa University Press.

[13] Gulland, F. M. D., Fox, M., 1992. Epidemiology of nematode infections of Soay sheep (ovis aries L.) on St. Kilda. Parasitiology, 105: 481-492.

[14] Kuchay, J. A.; Chishti, M. Z.; Zaki, M. Manal; Javaid Ahmad, 2011. Prevalence of nematode parasites in sheep of Ladakh-India. Journal of Agricultural Extension and Rural Development, 3 (13): 229-231.

[15] Laha, R.; Ramakrishna, C.; Bhattcharya, D. and Sikdar, A. 2001. Seasonal incidence of Haemonchus contortus infection in goats- a post-mortem study. Indian Journal of Animal Sciences, 71: 345-346.

[16] Patel. M. D., Nauriyal, D. S., Hasnani, J. J. and Gupta, R. S. 2001. Prevalence of gastrointestinal parasitism in goats maintained under semi- intensive and filed management systems. Indian Journal of Veterinary Medicine, 21: 99-101.

[17] Soulsby, E. J. L. 1982. Helminths, Arthropods and protozoa of Domesticated animals, 7th Ed. The English Book society and Bailliere Tindall, London.

[18] Nasreen, S.; Jeelani, S. G. and Munir, H. 2005. Incidence of gastrointestinal nematodes in sheep in Kashmir valley. J. of Vet. Parasitology, 19(1): 27-29.

[19] Yamaguti S (1959). Systema helminthum volume 1 inters science publishers.

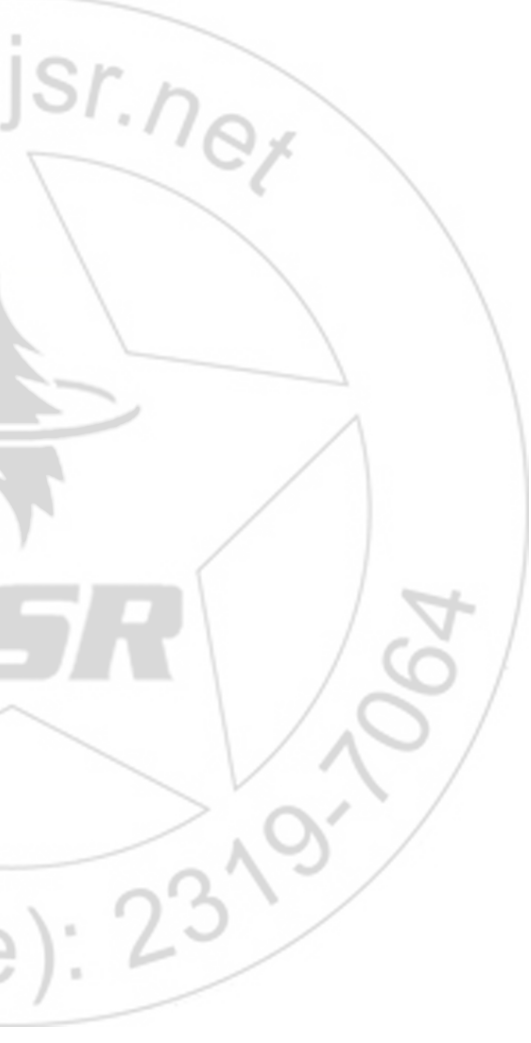

Volume 5 Issue 5, May 2016 